\title{
PANCASILA IDENTITY AMONG MILLENNIAL GENERATION IN THE GLOBALIZATION ERA
}

\author{
Feren Alia Hidayat ${ }^{1}$, Moses Glorino Rumambo Pandin ${ }^{2}$ \\ ${ }^{1}$ Faculty of Psychology, Airlangga University Surabaya \\ ${ }^{2}$ Faculty of Humanities, Airlangga University Surabaya \\ feren.alia.hidayat-2020@psikologi.unair.ac.id; moses.glorino@fib.unair.ac.id
}

\begin{abstract}
Pancasila is the identity of the Indonesian nation, which means that Pancasila is a national characteristic that cannot be found in any country. Pancasila points are taken from the noble values of the Indonesian state. These principles contain culture, customs, and national character known as manners, cooperation, and high nationalism. As the successor to Indonesian culture, the young generation must be able to preserve and develop Pancasila. In this era of globalization, there are many challenges for the younger generation in preserving Pancasila. This study aims to provide an overview of the decline of Pancasila identity among the younger generation due to the impact of globalization. The research question that has been determined is how the practice behaviour of the younger generation towards the implementation of Pancasila, the solutions and efforts that all Indonesian people can make regarding the crisis of Pancasila identity in the era of globalization. This research method uses a literature review. The research sources were conducted from the latest journals and books published in 2019 until 2021 related to the theme of Pancasila and the millennial generation. The results showed that globalization has greatly facilitated foreign cultures to enter Indonesia. The younger generations use this foreign culture as a lifestyle without filtering it, whether it contains Pancasila values or not. This causes Pancasila has been forgotten and no longer applied in their everyday life. Young people can make various efforts to preserve the national identity, namely Pancasila. Apart from the role of the young generation itself, Indonesian society can also play an essential role in supporting the younger generation to continue implementing Pancasila in their lives. By conducting this research, it is hoped that Indonesia's young generation can understand, select, and stay away from the negative impacts of globalization that enter Indonesia freely. The solution that can be given from this research is that the younger generation must love their own culture more and practice every principle in Pancasila. Parents, educational institutions, and the government must also support the younger generation to maintain national identity, Pancasila values. The limitation of this research is that the researcher did not conduct any primary data, which means the data were not directly from the source. This causes the accuracy of this study to be less guaranteed. The recommendation that the researchers can give for further research is to obtain primary data to ensure accuracy and explore research topics regarding the fading of Pancasila identity in the younger generation in this era of globalization.
\end{abstract}

Keywords: Pancasila, Young Generation, Globalization.

\section{INTRODUCTION}


Pancasila is the formulation and guidelines for the life of the Indonesian people as a nation and state. Pancasila has a strong, irreversible, and permanent position because it is the core of the preamble to the 1945 constitution. As a sacred philosophy, Pancasila has a vital function and position in Indonesia: as philosophy basis, national identity, and distinctive characteristics for the Indonesian nation, as well as the principle of national unity. When the Indonesian state was founded, Pancasila was the result of an agreement from the founding fathers to become the basis and ideology of the state - an ideology that is open, dynamic, and reformative (3). By dynamic, it means that Pancasila can keep up with the times. It is an open system of thinking. Pancasila is also the result of consensus from the Indonesian people, so that Pancasila should have been manifested in the life of the state and nation. The role of Pancasila as the state ideology is a cultural bond. This means that Pancasila is ingrained in the lives of all Indonesians.

Practicing the principles of Pancasila is the obligation of all Indonesian citizens, especially the millennial generation, as the nation's hope for the future. However, as time goes by, Pancasila values have faded and shifted towards values that are not contained in Pancasila. This happens in the current situation of Indonesian millennials. In this globalization era, there are various kinds of western cultures that can easily enter Indonesia. The impact of these foreign cultures mostly contradicts the values of Pancasila. For example, the younger generation has a westernized lifestyle, wears revealing clothes against the prevailing norms in Indonesia, prefers modern dances to traditional dances, and many other Indonesian cultures are left behind. The younger generation does not implement Pancasila in their lives and does not make Pancasila the national personalityresulting in a character crisis for the cultured younger generation (3).

This study aims to determine the meaning of Pancasila, the role and function of Pancasila, the implementation of the Pancasila principles, the behavior of the millennial generation that deviates from the Pancasila principles, the definition of globalization, the negative impact of globalization on the younger generation, and efforts to re-apply the Pancasila values among millennial generations. In addition, this study also aims to provide an overview of the decline of Pancasila identity among the younger generation due to the impact of globalization. From the objectives that have been determined, the researcher determine several research questions, namely: 1. How is the attitude of the younger generation towards the implementation of the principles of Pancasila; 2. What are the solutions and efforts that can be made by all Indonesian people, especially the younger generation, about the identity crisis of Pancasila in the era of globalization? 


\section{METHOD}

The research method used in this study is literature reviews. According to Snyder (2019), literature reviews can be described as a systematic way to collect and synthesize previous research. Literature reviews can create a solid foundation for advancing knowledge and facilitate theory development. By integrating the findings and perspectives of many empirical findings, literature reviews can answer research questions better than a single study. Researchers make summaries, conduct analyzes, and perform in-depth and critical syntheses from a collection of journals and books that have been collected (11).

Literature reviews have several stages. The first stage is collecting library materials to gather relevant information in journals and books according to the research theme. This stage aims to avoid duplication and find out what research has been done. Next, read, understand, and internalize the library material that has been collected, then take notes of all the important parts. The next stage is processing and analyzing notes containing these important points. Lastly, conclude the materials that will be discussed (11).

This study uses data collection techniques by collecting documentation from relevant journals and books. The source of the articles that the researcher uses are journals from google scholar. The data used in this research is secondary data, namely journals and books published in 2019-2021 with Pancasila and the millennial generation as the theme. After collecting journals and books, the researcher will conduct an assessment.

The technique used in this research is the content analysis technique by taking the essence of the information and the results of thought so that it can draw conclusions that are in accordance with the research theme. The descriptive-analytic technique is also used by describing the data found so that it can be used to answer the problems examined in this study. Lastly, using inductive analysis techniques by organizing various things related to the experiences you already have according to the theme to be discussed (7).

It is hoped that by using literature review with this data collection technique, it will be easier for the researchers to provide some information about the fading of the identity of Pancasila 
in the era of globalization and efforts to re-instill the values of Pancasila in the future generation of the nation who are expected to make better changes for their country.

\section{RESULTS}

Etymologically, the origin of the name Pancasila is taken from Sanskrit (Indian Brahmin language). The word "Panca" means five, and the word "Sila" means principle. Therefore, in terms of language, it can be concluded that Pancasila is the five principles used as the way of life of society and the basis of the Indonesian state. In addition, the word "Sila" also comes from the word "Susila" which means good behavior. Therefore, Pancasila can also be interpreted as the five good behaviors (5).

In terminology, Bung Karno named his proposal regarding the five basic principles of the Indonesian state under the name "Pancasila" at the BPUPKI meeting on June 1, 1945. After going through a debate of different opinions, the founders of Indonesia finally agreed on five principles to be used as the basis of life for Indonesians. Thus, Pancasila has also begun to become the identity of the Indonesian nation at the same time as the events leading up to Indonesia's independence on 17 August 1945 (5).

Pancasila has an important role and position for Indonesia. It is a way of life and the determinant of national identity as the state ideology. A country's ideology is used as a guide to overcoming the challenges in its development. Pancasila is dynamic and reformative. Pancasila can be interpreted as the crystallization of values that come from the noble life of the Indonesian people; therefore, it must be a basis and reference in making decisions when facing problems and a reflection of the behavior of Indonesian people in their lives. As a source of norms, Pancasila is an unwritten law that controls various aspects of people's lives. While as a source of law, Pancasila is the source of law for all problems in Indonesia. Pancasila is also the foundation for the national legal system.

Pancasila has a role as the ideals and goals of the nation that the Indonesian nation will achieve. This role means that Indonesian society adheres to the Pancasila ideology. The values of Pancasila are contained in the Preamble of the 1945 Constitution, Paragraph II contains the ideals and values of Pancasila in the Preamble of the 1945 Constitution, Paragraph IV contains national objectives. Pancasila is the national personality because it was absorbed from the values that have 
grown and developed in Indonesian society. Therefore, it needs to be instilled in every individual of the Indonesian state. Pancasila is the nation's noble agreement because Pancasila is the final decision that all the founders have approved of as the state's five fundamental values, so all Indonesian people must practice it. As the state ideology, Pancasila becomes a direction and vision on organizing the nation's life by creating a life that upholds religious values, human values, values of unity, integrity, social values, and justice. Pancasila is the basis of the state, which means that all state administration in Indonesia must be based on Pancasila (14).

Indonesia has an open ideology that has three reformation elements. The first element is fundamental values, namely the idealistic dimension. Basic values are the five main values in Pancasila: divine values, human values, unity values, populist values, and justice values. Basic values are the ideals of the Indonesian people and have a permanent nature. Then, instrumental value. Instrumental value is the normative dimension of flexibility. Instrumental value is a medium or a tool for realizing basic values. Instrumental values include various kinds of norms and policies, such as GBHN, moral norms, legal norms, social norms, religious norms, and many more. Next is the practical values. Practical value is the dimension of reality. Practical values are the realization of fundamental values in life that policies or norms in Indonesia have processed. This practical value is real and always has a gap with the basic value. When there is a gap between practical and fundamental values, the normative dimension takes the role of mediator (5).

The behavior of the young generation in this era of globalization is very far from the values of Pancasila. The behavior itself results from all human interactions and experiences with the environment in the form of actions, attitudes, and knowledge. Behavior is a person's reaction or response to a stimulus from external (environment) or internal (themselves). Behavior is the entire manifestation of human life when interacting with the environment, from visible to invisible behavior and from what is felt and not felt (9).

In this advanced era of technology, there are still many individuals who are wrong in responding to the values of Pancasila when viewed from their behavior. There are still many deviant actions taken by the younger generation as if to erase the values of Pancasila. The actions of deviating from the Pancasila principles, for example, are that young people do not pray on time, do not help others and are individualists, have a low nationalism spirit, do not respect other people's opinions, do not cooperate, and many more. 
One of the reasons for the character of the younger generation who do not have the spirit of Pancasila is globalization. Globalization itself comes from the words "global" and "-ization". The word "global" comes from the word "globe" which means a world map with a round shape like a ball. Then, from the word "globe", the term "Global" was created, meaning covering the whole world. The word "-ization" means process. So, globalization means a process that will have an impact on the whole world. In general, the meaning of globalization is a process that connects and combines various fields into one, such as agriculture, economy, socio-culture, and politics from various countries around the world (4).

There are several characteristics of globalization, namely technological advances in all aspects, indirect cultural interactions and exchanges, the mutual need for state economic sectors, and the emergence of various disputes and problems. The impact of globalization on all Indonesian society under certain conditions is forcing them to adapt to global polarization and culture (13).

\section{DISCUSSION}

\section{The Implementation of Pancasila in Everyday Life}

Pancasila is a life requirement for Indonesian citizens, especially the younger generation. Pancasila has an important role and position for the Indonesian nation in implementing Indonesian governance and Indonesians' identity. The values in Pancasila must be implemented in solving problems to form a framework for the Pancasila identity in the younger generation. The values of Pancasila that must be applied include the first principle, "Belief in the God Almighty", which contains a noble character and has a function as an answer in religious life, humanity, society, justice, and the state. The first principle implies that God is in control of the whole world and its contents. Therefore, all human mindsets and actions must be based on God's will. Applying the first principles in Pancasila can be done by believing in God Almighty and maintaining piety, obeying all commands, and staying away from His prohibitions. In addition, this can be done by implementing an attitude of tolerance between religious believers, not forcing others to enter the religion we believe in, respecting freedom in choosing the religion we believe in, not degrading or insulting other religions and adherents of other religions (12).

The second principle value, "just and civilized humanity", contains the meaning of values and respect for others. The application of the second principle can be done by recognizing equal rights and obligations, recognizing that all societies are equal in the eyes of law, society, and 
religion, can prioritize tolerance and mutual respect among communities, establish friendship without differentiating ethnicity, religion, race, or culture, and dare to defend the truth and justice (12).

The third principle, "The unity of Indonesia", implies that humans must have differences and similarities with other individuals. The application of the third principle can be done by enlivening cultural differences as an attraction, instilling a culture of cooperation, and maintaining harmony. We have to build a high spirit of nationalism and preserve Indonesian culture such as dances, traditional clothes, language (12).

The fourth principle, "Democracy guided by the inner wisdom in the unanimity arising out of deliberations among representatives", implies that the people of Indonesia adhere to democracy by using common sense and prioritizing unity and consensus. Understanding that all Indonesian citizens have the same rights and obligations, especially because every human being is God's creature. The application of the fourth principle can be done by prioritizing the use of deliberation to get joint decisions, prioritizing justice and tolerance when expressing opinions, and the final decision on the outcome of the deliberation must be agreed upon by all deliberation participants because it is a mutual agreement (12).

The fifth principle, "social justice for the whole of the people of Indonesia, " contains the understanding that a population structure is prosperous, fair, and physically and spiritually healthy. Every human being has the right to act and behave fairly because social justice can only be manifested if the entire community develops a fair attitude towards others. The application of the fifth principle can be done by developing and prioritizing fairness towards others, respecting the rights of others and carrying out obligations, and prioritizing welfare and prosperity for all communities rather than personal or group welfare (12).

\section{Millennial Generation Behavior}

At this time, the implementation of Pancasila values has not been carried out optimally in the life of the nation and state. Pancasila values are only used as a formality and a symbol. This resulted in the fading of the Pancasila identity in the younger generation and led to a moral crisis in Indonesia. The younger generation often performs actions contrary to Pancasila. They no longer use Pancasila as a reference in their life. 
In the first principle, there are deviant actions - there are still many young generations who do not perform worship on time. They also have a low tolerance for other religions. The younger generation rarely performs worship with family members and does not remind others to worship. They lack of religious knowledge. Sometimes they insult other religions and force other people to convert to their religion (2).

In the second principle, there are deviant actions-individualism, focusing more on gadgets, and ignoring the people around them. The younger generation doesn't care and help when someone is in trouble. There are often defenses against the wrong party, simply because that party is a friend. They lack of good manners and have low mutual respect. They lack ethics and manners in various circumstances (2).

In the third principle, there are deviant actions, namely that the younger generation has a low spirit of nationalism and self-sacrifice. They do not love their homeland and Indonesian culture. They do not maintain unity in society so that lots of splits happen. The younger generation is more concerned with personal interests than the interests of the wider community. Feeling not proud of the diversity that Indonesia has (2).

In the fourth principle, there are deviant actions, namely the attitude of disrespecting the opinions of others during deliberations or discussions because they consider their own opinions to be the most correct, do not attend meeting invitations from organizations or committees, and impose or influence the choices of others during general elections. In addition, many young generations do not solve problems using deliberation, are not big-hearted enough to accept other people's opinions, force their opinions to others, do not accept the results of joint decisions, and are not responsible for their decisions (2).

In the fifth principle, there are deviant actions, namely favoritism in social interactions, cooperation is increasingly fading, not obeying traffic rules, not maintaining public facilities, throwing garbage out of place, doing corruption even if only a little, refusing to help when there are other people who need help, are unfair in the distribution of rights and obligations and do not maintain harmony (2).

\section{The Negative Impact of Globalization on the Young Generation}

Globalization has had several negative impacts on the younger generation. These impacts put the behavior and lifestyle of the younger generation contrary to the values of Pancasila. The 
identity of the local culture is starting to decline due to the entry of western culture. Various Indonesian traditions, cooperation, manners, and many other local wisdom are fading away and displaced by western culture. This culture is synonymous with violence, individualism, anarchism, consumerism, and instant, which is the root of the ideology of liberalism, capitalism, which was brought by globalization. Globalization is an accelerating instrument in the spread of western culture, which causes the younger generation to experience dislocation and disorientation that threatens community solidarity and cohesiveness (10).

The occurrence of globalization and modernization in Indonesia has caused a shift in people's attitudes and values of Pancasila. There are several negative effects of globalization. The first is a consumptive lifestyle. The development of industrial revolution 4.0, which has become increasingly advanced, has made the provision of goods needed by the community in abundance and has made the younger generation more attractive to buy goods with the various options available. Goods from abroad can be purchased easily. Even foreign products have been sold in Indonesia. As a result, they lose their love for local products - a lack of nationalism (6).

The negative impact of globalization is individualism. In this era of globalization, the young generation is facilitated by high technology, which causes young people to feel like they don't need other people to live. As a result, they are more selfish and forget that they are social creatures. This has led to indifference between citizens and the fading of the culture of cooperation embedded in Pancasila (6).

The last negative impact of globalization is a westernized lifestyle. The younger generation absorbed western culture without selecting it first and made it a lifestyle. Not all western culture is suitable and good to be applied in Indonesia. This happens because western culture is identified as modern while eastern culture, including Indonesia, is traditional and conventional. Western culture has begun to shift Indonesian culture, such as the younger generation having lost courtesy and respect for their parents. The younger generation also has a freer life. They prefer dances, songs, and even western restaurants to Indonesian dances, songs, and food. Young people also like to wear revealing clothes. This is because the millennial generation, as the nation's successor, is not proud and does not love the nation's culture (6).

\section{Efforts to Instill the Value of Pancasila in the Millennial Generation}


The application of Pancasila in daily life is one of the roles of Pancasila as the nation's way of life. The Indonesian nation must practice the values of Pancasila. If this is not done, the goals and ideals of the nation will not be manifested. Therefore, various efforts are needed to re-instill the values of Pancasila in the younger generation. One of the efforts to implement the values of Pancasila is character education. Character education teaches ways of thinking and behaving that can shape the character of the younger generation and help in carrying out their lives (3).

The younger generation must build and develop the character of nationalism through three processes. The first process is character builder. With character builder, the younger generation has a role in building the positive character of the nation with a strong determination to uphold moral values and implement them into life. The next process is a character enabler-the younger generation can be a role model for developing a cultured and positive national character by developing collective awareness with high cohesiveness, such as resolving disputes and conflicts. The last one is a character engineer. The younger generation has a role in having achievements in the fields of science and culture and playing a role in the development of the positive and relevant character of the nation (8).

The five points of Pancasila must be applied correctly by the younger generation. The application of the first principles can be done by believing in one religion, maintaining devotion to God, and carrying out the worship of their religion. Do not force other people to believe in the religion they believe in because everyone has the right to choose a religion according to their respective beliefs. Then, the application of the second principle can be done by always respecting the differences in society because Indonesia has various ethnicities, religions, races, and cultures. Maintain good ethics and manners in all conditions. Next, the application of the third principle can be done by loving the country to maintain unity in society and developing the creativity of the younger generation to produce the nation's work. Furthermore, the application of the fourth principle can be carried out by supervising and providing advice on the administration of people's sovereignty by the government and prioritizing decision-making using deliberation to resolve a problem, whether for the interests of two or more people. Lastly, the application of the fifth principle can be done by always intending and trying to help others who are in trouble, appreciating the results of deliberations even though they are contrary to one's own opinion, and having the courage to fight for justice for oneself and others (2). 
The moral crisis of Indonesia's young generation due to the fading of the Pancasila identity must be immediately affirmed so that the younger generation will not stray further away from the values of Pancasila. Instilling Pancasila values is essential for creating a nation with internalized Pancasila values. Efforts to develop a high sense of nationalism in the younger generation are the millennials' responsibility and require the role of families, educational institutions, and the government as state administrators. The first role is the role of the family-by being an example of having a sense of love and pride in the Indonesian nation by telling what the late heroes have done for Indonesia's independence. In addition, parents must also supervise the environment around their children and ensure that young people grow up in a good environment. Then, parents must be an example for children in loving Indonesian products by using and boasting domestic products rather than foreign products.

Next is the role of educational institutions. The role of educational institutions in developing nationalism in the younger generation is by increasing learning about Pancasila and Civics Education and defending the country. This can be done by holding a flag ceremony every Monday to instill an attitude of love for the country and nationalism. Then, educational institutions must provide moral education so that the younger generation can be more selective in selecting things that can fade the identity of Pancasila. Hopefully, young people will not be easily influenced by various things that can decline the national identity.

Lastly is the role of the government. The role of the government in developing a spirit of nationalism in the younger generation is by holding various kinds of activities that can develop a sense of nationalism, such as local cultural exhibitions and seminars. Then, the government must listen to and respect the younger generation's aspirations so that Indonesia's development can be better (7).

There are also ways to develop cultural awareness in the younger generation, namely by instilling an attitude of multiculturalism starting from childhood, reducing the consumption of western culture, socializing Indonesian culture through educational institutions, and organizing various art performances that contain local culture, love, and promote the culture of the nation (1).

\section{CONCLUSION}

Pancasila has many important roles and positions for the Indonesian state. Pancasila is the basis and guideline for all Indonesian people. The values contained in Pancasila are fundamental 
philosophical points and are used as the basis for the rules of the norms and policies applied in Indonesia. Pancasila has also been designed in such a way to describe the noble values of the Indonesian people. In this era of globalization, there are many challenges on practicing the values of Pancasila. As time goes by, various foreign cultures enter Indonesia easily. The younger generation prefers western culture because it is considered more modern. Although western culture contradicts the values of Pancasila, western culture is still used as a lifestyle for young people. The younger generation does not make Pancasila their way of life, therefore the national identity is declining. Many young people have taken deviant actions as if to erase the values of Pancasila. The younger generation has also become more consumptive and individualistic. Not only do they love western culture, but they are more proud of foreign products than local products. The younger generation has low devotion and often insults other religions, does not help others when they are experiencing difficulties, has a low spirit of nationalism and love for their homeland, cannot respect other people's opinions, and considers their own opinions to be the most correct, as well as a soul coperation and manners are fading.

With the fading of the Pancasila identity as the basis of the Indonesian state, it is necessary to affirm and restore the role of Pancasila as a national identity. The younger generation must apply the five principles of Pancasila as a way of life. This is an important because the younger generation has abandoned Pancasila and has a character that is contrary to Pancasila. Efforts that young people can make include: maintaining piety and not forcing others to convert to a religion they believe in, respecting differences in society, loving the homeland to maintain unity, prioritizing decision-making through deliberation to reach consensus, and always helping other people who are in trouble. The younger generation must also love the Indonesian culture more so that they do not boast about western culture. This effort must be carried out by the successor of Indonesian culture and the role of the family, such as being an example of love and pride for the Indonesian nation by telling what the late heroes have done for Indonesia's independence. Apart from the family, educational institutions must also play a role in cultivating the values of Pancasila, namely by increasing learning about Pancasila and Civics Education and defending the country. And the last one is the role of the government, namely by holding various kinds of activities that can develop a sense of nationalism, such as local cultural exhibitions and seminars.

The limitation of this research is that the researcher does not obtain data directly from the source through interviews, surveys, filling out questionnaires, direct observation, and many other 
ways. This lowers the chances for the research to be accurate since there is a possibility of errors in the research data. Therefore, the recommendation that researchers can give for further research is to use methods to obtain primary data such as interviews, surveys, etc. to ensure accuracy further because research data is obtained directly by researchers and can further explore research topics regarding the fading of Pancasila identity to the younger generation in this era of globalization.

\section{REFERENCES:}

1. Aidah SN. Steps to Awaken a Cultured Young Generation: Getting to Know Indonesian Culture, Efforts to Preserve Indonesian Culture, How to Slang Cultured Millennials and the Role of Language in Intercultural Communication. First Editon. Bojonegoro: Indonesian KBM Publisher; 2020. 71 p.

2. Anggraini D, Fathari F, Anggara JW, Ardi Al Amin MD. The Practice of Pancasila Values for Millennial Generation. JISoP. 2020 Apr 2; 2 (1): 11.

3. Ashifa R, Dewi DA. Implementation of Pancasila Values as a Strategy for National Character Development in the Era of Globalization. 2021; 12:12.

4. Dewi SL. Building National Civilization in the Era of Globalization of Character Education. Pen Mahakam J Basic Educator. 2020 Jan 13; 4 (1): 48-54.

5. Gultom A. Implementation of Pancasila in Maintaining the Nation's Existence. 2019; 30: 12.

6. Komariah K. Challenges in the Millennial Era in Counteracting Foreign Culture by Promoting an Attitude of Nationalism. 2020 Jun 1;21: 8.

7. Lestari AS, Aini M. Keprah Milenial Generation In Era 4.0 In Earthing Pancasila. 2019; $3: 21$.

8. Lestari EY, Janah M, Wardanai PK. Developing the Nationalism Awareness of the Young Generation in the Era of Globalization through the Application of Pancasila Values. 2019; 1: 8.

9. Septianingrum AD, Dewi DA. The Implementation Of Pancasila Value In The Millennial Generation In The Era Of Modernization. 2021; 3: 8.

10. Sholahudin U. Globalization: Between Opportunities and Threats for Indonesia's Multicultural Society. 2019; 4 (2): 12.

11. Snyder H. Literature review as a research methodology: An overview and guidelines. Journal of Business Research. Nov 2019; 104: 333-9.

12. Sukmalia M, Dewi DA. Sustainability and Implementation of Pancasila Values in Community Life. 2021; 6.

13. Wulandari AD, Dewi DA. The Urgency of Grounding Pancasila for the Character of the Nation's Successor in the Era of Globalization. 2021; 5: 5.

14. Yunianti VD, Dewi D. Implementation of Pancasila Values In Community Life. 2021; 3: 6.

15. Azzahra, S. S., Pandin, M., \& Pandin, M. The factors of bullying and character education on teenagers. 2021. April, 1-9. https://doi.org/10.20944/preprints202104.0102.v1 
16. Khansas, A., Kumala, D., \& Pandin, M. Archipelago Insights as Efforts to Establish National Geostrategic Resilience: A Literature Review. Preprints, 2021; May. https://doi.org/10.20944/preprints202105.0154.v1

17. Munir, M., Glorino, M., Pandin, R., Mada, U. G., Trilogi, U., Airlangga, U., Airlangga, U., \& Java, S.-E. Human Resource Information System and Work Stress during COVID-19 Pandemic. 2020; December, 1-14. https://doi.org/10.20944/preprints202012.0469.v1

18. Wicahyanti, P. A., Rahim, N. A., Glorino, M., \& Pandin, R. The Awareness of Millennial Generation during Covid-19 Pandemic towards State Defense Character. 2021; May, 1-12. https://doi.org/10.20944/preprints202105.0122.v1 